試料・メタノール，硫酸の混命物を州熱㩭拌し反㮣せしめるか，試料飞五監化燐を加え酸クロライ ドとなしてれへメタノールを注をチルェステルとした。

\begin{tabular}{|c|c|c|c|c|c|c|c|c|c|c|c|}
\hline \multirow{3}{*}{$\begin{array}{l}\text { 籡 } \\
\text { 番 } \\
\text { 諕 }\end{array}$} & \multirow[t]{3}{*}{ 試 } & \multirow[t]{3}{*}{ 料 } & \multicolumn{2}{|l|}{ 硫 } & \multirow{3}{*}{$\mid \begin{array}{r}\text { F..殈化燐 } \\
\mathbf{g}\end{array}$} & \multirow{3}{*}{ 㶮 } & 生 & 成 & 物 & & \multirow[t]{3}{*}{ 末反碓酸 } \\
\hline & & & \multirow{2}{*}{ 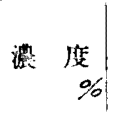 } & \multirow[b]{2}{*}{$\mathrm{cc}$} & & & \multicolumn{2}{|c|}{ テレフタール酸メチル } & \multicolumn{2}{|c|}{ トル亡ン酸メチル } & \\
\hline & & & & & & & B. P. & $\bar{g}$ & B. P. & $\mathrm{g}$ & \\
\hline 1 & C 3 & 24.9 & 92 & 20 & - & 120 & $147 \sim 148(5)$ & 17.5 & $215 \sim 218$ & 2 & - \\
\hline 2 & M 3 & 25 & 80.5 & 100 & - & 190 & $163 \sim 167(16)$ & 17.0 & & - & 5.5 \\
\hline 3 & M 4 & 25 & 100 & 10 & - & 150 & $163 \sim 167(16)$ & 22 & & - & 0.8 \\
\hline 4 & M 6 & 10 & - & - & 34 & 80 & & 12 & & - & - \\
\hline
\end{tabular}

ロ, N5生成物のエチルェステル

試料 $27 \mathrm{~g}$, 無水厂ルコール $55 \mathrm{~g}, 95 \%$ 硫酸 $20 \mathrm{cc}$ の混合物を 5 時間加熱反應せしめ，反應物を椧 後水注ざペンゼルより抽出, 中和, 水洗, 乾燥後蒸溜す。

\begin{tabular}{|c|c|c|c|c|c|c|c|}
\hline & • & 蒸 & 溜 & 物 & & 末反嵟物 & \\
\hline B. P. ${ }^{\circ} \mathrm{C}$ & $\stackrel{a}{a}$ & $\begin{array}{c}b \\
228 \sim 24\end{array}$ & $\begin{array}{c}c \\
246 \sim 260\end{array}$ & $\begin{array}{c}d \\
260 \sim 285\end{array}$ & 殘 & & $\mathrm{d}$ 溜分はクロルメチル安息 \\
\hline 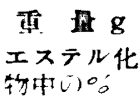 & $\begin{array}{l}1.0 \\
5.0\end{array}$ & $\begin{array}{r}2.2 \\
11.2\end{array}$ & $\begin{array}{r}3.4 \\
17.4\end{array}$ & $\begin{array}{l}11.2 \\
57.5\end{array}$ & $\begin{array}{c}2 \\
11.0\end{array}$ & 2 & 香酸エチルと思われる。 \\
\hline
\end{tabular}

\title{
結会
}

この貫騟はポリェステル系合成維維の一中間體たるテレフタール酸を入手し易き原料より收本よく 得る目的で行つたのであうか， $\mathrm{P}$-メチルベンヂルクロライドを先す硝酸で酸化し後過マンガン酸カ リで酸化する方が最も良レと思われる。この反應では先ずークロルトルェン酸が出來ると云う事も同 時㴶めた。

女

1) J. R. Whinfield: Nature; 28930 (1946)

2) Meyer, Bernhauser; Monk. 721 (1929); Smith: J. A. C. S 431920 (1921)

3) Randall; Proc. Roy. Soc. A 165432 (1938)

4) Org. Syn. Coll. I. 112,

5) Blane; Bull. Soc. chim. 33313 (1923)

1949 年 10 月 12 日受理

第 2 報 ポリェチレングリコールテレフタレートの製造

鶴田基弘・黑木宣应・西村英治

テレフタール酸（或はそのエステル）とエチレングリコールの縮合に依り一段反應にてスーパーポ

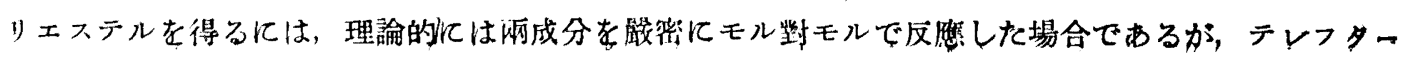


ル酸を用いるとしろそのメチルェステルを用いるどしろ何れも昇華性を有する篇, エチレングリコ一 ルとのモル此を全反䭒中同一に保つ事は困難である。然しCarothers等の用いた方法”郎ちェチレン グリコールの方を過剩になる如くして反應せしめ，低分子縮合體を得を後減㷴にて熱して過剩のグ ・リコールを除くと同時にポリマー交換反應 "2を行わしめてスーパーポリマーを得る方法に依れば高重 合度のものが得られると思レ，ての方法を探る事にした。上記の如くテレフタール酸及びそのエステ ルは何れも年華性なるが故に，モル對モルで縮合せしめても゙グリコールの方が過剩となる故に，始め の費驗はモル對モル或はグリコールを稍々過剩に用レる事にした。所が最初の筫驗開始後見る事を得 たChein. Abst. 中のWhinfield, Dickson の特許 ${ }^{3)}$ との方法を探用しているが，エステル對グリコ 一ルのモル此は 1:1.5でありグリコールを相當過剩に用んているので吾ふもての附近のモル比を探つ て賽驗を行なつて見た（ての外“Terylen”關係の特許としては Cook "), Hugglli, Wielch, Dickson ${ }^{5)}$ の特許がある)。

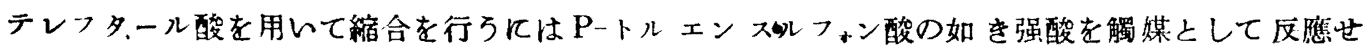
しめるのであるが，テレフタール酸に触點がない䉆に反應不妁一となるのでメチルェステルを用い，

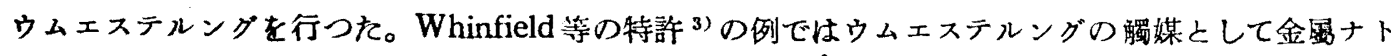
リウムを與げてレるか，吾々はその他䅉水炭酸加里，無水炭酸曹達を用いて見て，てれ等の方が減 㻺下の前熱の際突沸を起さす操作が樂であつたので, 主としててれを用いた。しかしNaの方がウム エステル化の速度は少し速い榚である。減嫄度は成る可く高いすが良く, 出來得れば分子蒸溜が望ま しいのであるが工業的に筫施の場合を考應に入れて, $2 \sim 3$ ミリ水銀柱程度に止め，反應時間を長くす る事によつて重合度（融點）を上げんとしたが，大體 $250^{\circ} \mathrm{C}$ 程度の融點のものは得られたが重合物は 稍々着色した。

\section{驗の 部}

筫騟方法はテレフタール酸メチル,エチレングリコール,及び觸媒を悹素がス对炭酸ガス氣流中比

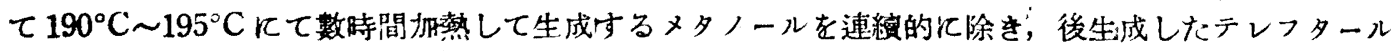
酸ダリコレ゙ートを $280^{\circ} \mathrm{C} \sim 285^{\circ} \mathrm{C}$ にて若千時間加熱後，同溫度にて減盟下に數十時間加熱を行万方法 で, Whinfield 等の特許例之大䯘同一條件である。得られた樹脂は $235^{\circ} \mathrm{C}$ 以上の高融點の灰白色乃至 淡褐色を呈する物睤で非常に硬いが脆い。ニトロベンゼンには熱時可溶であるが，高溫の粘度測定は 不能なので，割に銃敏な融點を有する故てれを重合度の目安とした。

質驗結果の一部を示すと第1表の如し。

No. 1,2 はモル對モルの反應。No. 3,4,5 は約 1:1.5（酸：グりコール）での反應。No. 4 は特培通り 行つた簤騟である。

No.7はエステルでなくテレフタール酸とエチレングリコールをハラトルェンスルフォン酸を觸媒之 してェステル化せる筫駼であるが前述の如く妇一なポリマーよならなからた。

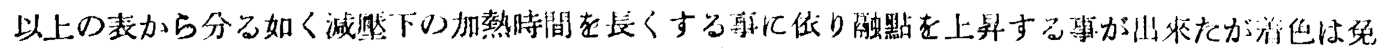




\begin{tabular}{|c|c|c|c|c|c|c|c|c|}
\hline \multirow{3}{*}{ No } & \multirow{3}{*}{ 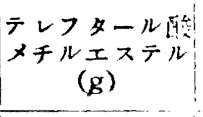 } & \multirow{3}{*}{$\begin{array}{l}\text { エチレングリ } \\
\text { エール } \\
\quad(\mathrm{g})\end{array}$} & \multirow{3}{*}{ 解 $(\mathrm{g})^{\text {媒 }}$} & \multirow{3}{*}{ 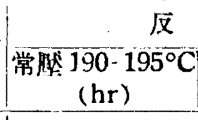 } & \multirow{3}{*}{ 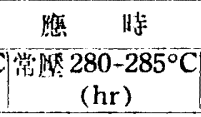 } & \multicolumn{2}{|c|}{ 閒 $(\mathrm{hr})$} & \multirow{3}{*}{ 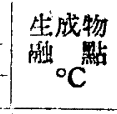 } \\
\hline & & & & & & \multicolumn{2}{|c|}{ 娍阷 $280-285^{\circ} \mathrm{C}$} & \\
\hline & & & & & & $\mathrm{mm}$ & $\mathrm{hr}$ & \\
\hline 1 & 5.0 & 1.60 & $\begin{array}{l}\mathrm{K}_{2} \mathrm{CO}_{3} \\
0.02\end{array}$ & $\mathrm{CO}_{2}{ }^{*} 10$ & 1.5 & 5 & $\begin{array}{l}22^{* *} \\
26(48)\end{array}$ & $\begin{array}{l}235 \\
245\end{array}$ \\
\hline 2 & 150 & 4.85 & $\begin{array}{c}\mathrm{Na}_{2} \mathrm{CO}_{3} \\
0.0138\end{array}$ & $\mathrm{~N}_{2}{ }^{*} 0.5$ & 0.5 & 7 & 10 & 236 \\
\hline 3 & 5.0 & 2.00 & $\begin{array}{l}\mathrm{K}_{2} \mathrm{CO}_{3} \\
0.03\end{array}$ & $\mathrm{CO}_{2}{ }^{*} 10$ & 3.0 & 5 & 24 & $240-242$ \\
\hline 4 & 10.0 & 4.85 & $\begin{array}{r}\mathrm{Na} \\
0.003\end{array}$ & $\mathrm{CO}_{2}{ }^{*} 3$ & 0.5 & $1-\dot{3}$ & $\begin{array}{l}10 \\
13.5(23.5)\end{array}$ & $\begin{array}{l}239 \\
247\end{array}$ \\
\hline 5 & 5.0 & 2.00 & $\begin{array}{c}\mathrm{K}_{2} \mathrm{CO}_{3} \\
0.02\end{array}$ & $\mathrm{CO}_{2}{ }^{*} 5$ & 1.0 & $1-2$ & $\begin{array}{l}29 \\
14(43) \\
8(56)\end{array}$ & $\begin{array}{l}239-293 \\
244-49 \\
247-50\end{array}$ \\
\hline 6 & $\begin{array}{c}\overline{\mid} \\
5.0\end{array}$ & 2.34 & $\begin{array}{l}\text { P.T.S.A. } \\
0.05\end{array}$ & $\mathrm{CO}_{2} * 10$ & 4 & 7 & 21 & $230-4$ \\
\hline
\end{tabular}

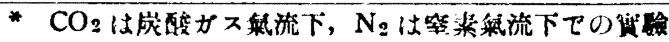

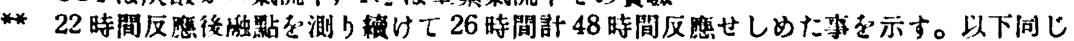

+ P. T. S. A はPトルエンスルラォン酸

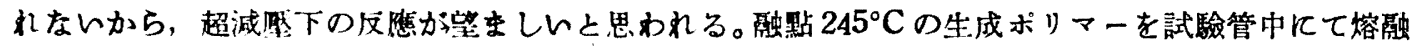

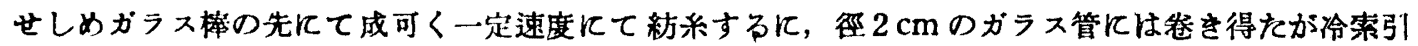
をせんとするも出來なかつた。强度は割保强い樣なるも伸度が殆んどなく，脆い維維であつた。紡系 ．の方法及び冷䋕引の方法を更に研究すれば良好なものが得られるかも知れない。この筫驗に使用した ポリマーは, 紡系のゃり方で著しい差を示した。郎ち緊張の度合倿り可撓性が大へん違い紡系はナ イロンより大分困難である。

前迅せる如く伸度が大一ん小さかつたのでその强伸度も測定する事が出來ず，ポロポロ折れる仕末

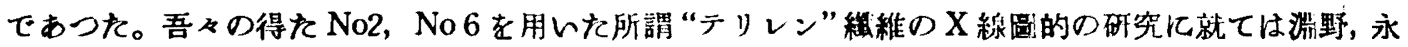

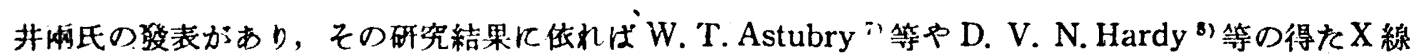
測と同样の圆形を得ている。

\section{結铻}

吾くはテレノタール睃及びェチレングリコールよりスーパーポリエステルを得て，奖國にて發表さ

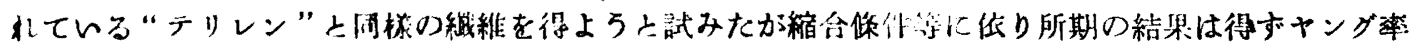
の高い維稚を得た。然し結晶形は Astubry等の發表している“テりレン”之同樣のものであつね。べ ンソール核の入つたボリマーとしてはポリスチレンや村橋氏等に依り研究されなポりてミド等があり

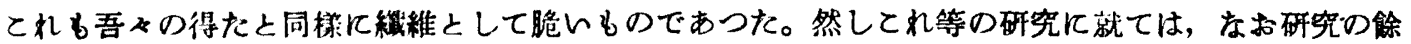
地があり今後得てての方面の研究を行いたいと思う。

*

1) Carothers: Chem. Rev. 8353 (1931); Carothers and Dorough: J. A. 52, 711

2) Flory: Chem. Rev. 39137 (1946)

3) Whinfield, Dickson; B. P. 578,079 (1946) C. A. 411495

4) Cook: B. P. 590, 417 (1947) C. A. 42, 414

5) Huggli, Diekson and Weleh: B. P. 590, 451 (1947) C. A. 42, 414

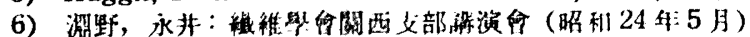

7) IV. T. Astubry and C. J. Brawn; Nature 158. No. 4024

8) D. V. N. Hardy and W. T. Wood: Nature 159, No. 4046

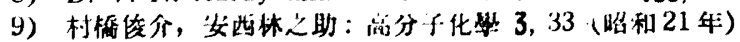

